\title{
Inovasi Kerajinan Serat Paku Hata (Lygodium circinatum) Khas Citumang, Jawa Barat
}

\author{
Fajar Ciptandi ${ }^{1 *}$, Rachmah Firstriani², Sisca Dewi ${ }^{3}$ \\ ${ }^{1}$ Departement Master of Design, Faculty of Creative Industries, \\ Telkom University, Bandung, Indonesia \\ ${ }^{2,3}$ Department of Craft, Faculty of Creative Industries, \\ Telkom University, Bandung, Indonesia
}

\begin{abstract}
In Citumang Village of Pangandaran Regency in West Java, Hata ferns (Lygodium circinatum) plants thrive. Citumang people use the abundance of this plant to make handicraft products such as bags, hats, and wall hangings. However, the products made by Hata ferns craftsmen at Citumang do not yet have their characteristics, so often, their bags are said to be the same as crafts in Bali and Lombok. That is due to the lack of development in design, colors, and techniques of the Citumang Hata ferns handicraft products. Experiments on natural coloring, structural design, and motif composition designs were carried out to enhance the characteristics of the handicraft,. Thus Hata ferns craftsmen at Citumang can innovate by applying the experiment to bag products. The experiment finally succeeded in showing the characteristics of Hata ferns handicraft products with makes it more aesthetic. This experiment also helped develop creativity and add insight into the craftsmen at Citumang.
\end{abstract}

\section{Keywords}

Citumang village, hata ferns, craft, natural fiber 


\title{
Inovasi Kerajinan Serat Paku Hata (Lygodium circinatum) Khas Citumang, Jawa Barat
}

\author{
Fajar Ciptandi, Rachmah Firstriani, Sisca Dewi
}

\section{PENDAHULUAN}

Gambar 1. Produk kerajinan Paku Hata Khas Bali dan Lombok (Sumber: Firstriani, 2018)

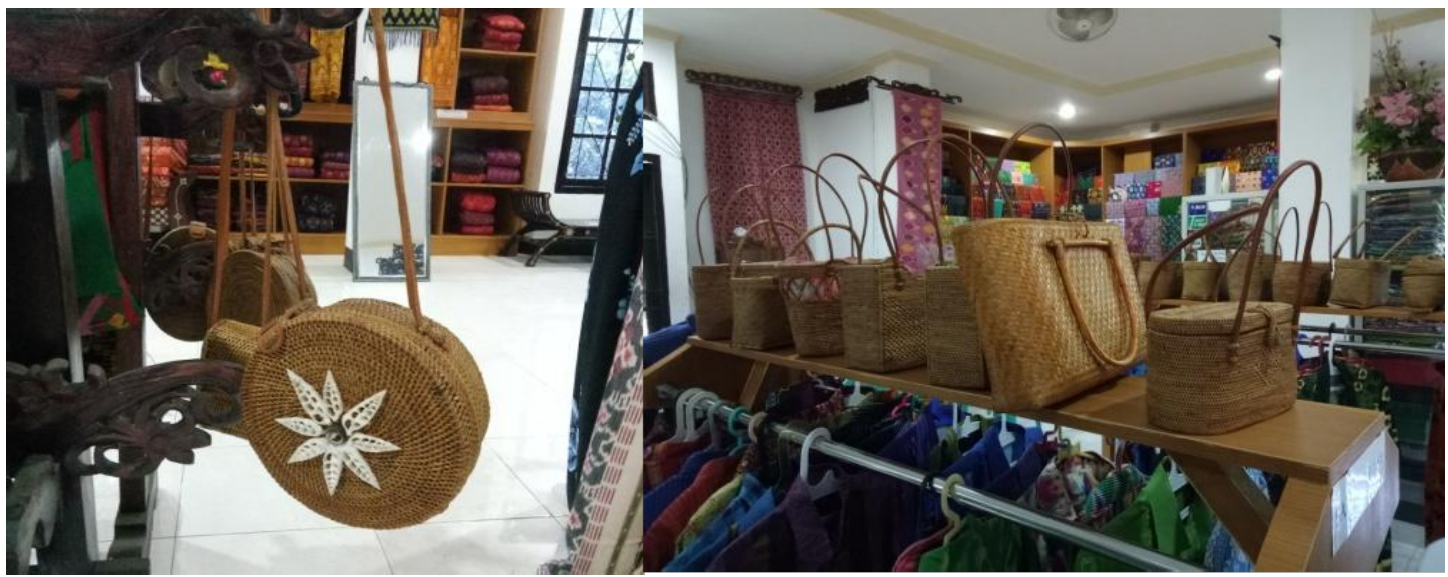

Desa Citumang, Kabupaten Pangandaran di Jawa Barat memiliki potensi sumber daya alam yang besar berupa hasil pertanaman serat paku hata. Tumbuhan ini bahkan telah menjadi sumber penghasilan bagi masyarakat Citumang yang berprofesi sebagai pengrajin dengan mengolah serat paku hata sebagai bahan baku untuk pembuatan berbagai produk kerajinan [1]. Tumbuh-tumbuhan paku sebetulnya merupakan tumbuhan yang mudah ditemukan di berbagai tempat mulai dari wilayah hutan hingga tepi jalan. Khusus tanaman paku hata yang tumbuh di kawasan Jawa Barat sendiri lebih banyak tumbuh secara liar di kawasan pesisir. Selama ini tanaman paku hata banyak dimanfaatkan oleh masyarakat sebagai bahan pengobatan, bahan makanan hingga kerajinan [2].

Pada tahun 2015, para pengrajin serat paku hata di Citumang bersama dengan Dinas Perindustrian Kabupaten Pangandaran melakukan kerja sama melakukan workshop pengembangan inovasi desain pada produk kerajinan serat paku hata dalam rangka upaya peningkatan potensi serat paku hata di bidang kerajinan. Dinas Perindustrian Kabupaten Pangandaran merealisasikan kegiatan tersebut dalam bentuk program pelatihan keterampilan menganyam dan proses produksi kerajinan paku hata menjadi aneka produk tas kepada masyarakat Citumang Berdasarkan hasil pelatihan tersebut, hingga kini masyarakat Citumang telah mampu menghasilkan produk-produk kerajinan berbentuk tas dengan aneka bentuk. Namun, permasalahannya adalah desain tas tersebut belum memiliki karakteristik yang khas mewakili identitas produk kerajinan masyarakat Citumang. Bentuk-bentuk pelatihan dan pendampingan desain yang diberikan nyatanya masih menghasilkan produk-produk kerajinan berup atas yang memiliki kemiripan dengan hasil produk kerajinan paku hata khas Bali dan Lombok [1][3].
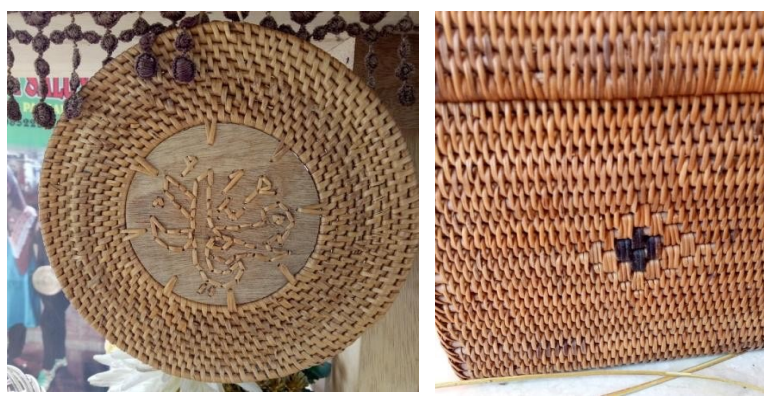

Gambar 2. Produk Kerajinan Paku

Hata Khas Citumang

(Sumber: Firstriani, 2018) 
Produk Kerajinan berupa tas anyaman khas Citumang ini sendiri dalam proses pembuatannya menggunakan teknik anyaman coil. Teknik Coil ini merupakan salah satu teknik menganyam batang yang diawali dengan membentuk lingkaran pada bagian tengah bawah anyam lalu kemudian dililit dengan benang atau helaian serat sehingga lingkaran yang terbentuk akan semakin besar dan tersusun hingga menjadi sebuah keranjang [4].

Dalam memanfaatkan potensi serat alami, yang dalam hal ini adalah serat tanaman paku hata, perlu untuk terlebih dahulu memehami betul sifat dan karakteristik serat untuk kebutuhan, antara lain: 1) pertimbangan mengolahnya pada saat proses pembentukan serat, 2) pertimbangan proses menghias dan mewarnai serat, dan 3) pertimbangan untuk pengaplikasian pada produk yang tepat sesuai karakteristik yang dimiliki oleh serat tersebut [5][6]. Selain itu perlu juga memperhatikan keterampilan dasar yang telah dimiliki oleh masyarakat pengrajin paku hata di Citumang itu sendiri [1]. Dengan melakukan hal-hal tersebut maka upaya mewujudkan produk kerajinan yang memiliki kekhasan produk mewakili masyarakat Citumang pun dapat terwujud.

\section{EKSPERIMEN PAKU HATA UNTUK MENCIPTAKAN INOVASI KERAJINAN KHAS CITUMANG}

Berdasarkan permasalahan yang dihadapi dalam pengembangan produk kerajinan paku hata tersebut, maka akan dilakukan proses ekperimen untuk menciptakan inovasi pada desain produknya. Proses eksperiman dilakukan dengan mengolah langsung serat paku hata yang merupakan bahan baku pembuatan produk kerajinan yang diperoleh secara langsung dari para pengrajin paku hata di Citumang itu sendiri. Dalam upaya menciptakan inovasi pada material serat bahan baku paku hata ini dilakukan dengan dengan pendekatan metodologi eksperimentatif. Eksperimentatif ini terdiri dari beberapa tahapan, yang pertama adalah tahapan pewarnaan, tahapan desain struktur dan tahapan komposisi motif.

\section{Eksperimen Proses Pewarnaan Alami Serat Paku Hata}

Selama ini produk kerajinan tas paku hata yang dibuat oleh masyarakat Citumang masih mengandalkan pewarna asli dari serat paku hata tersebut yaitu Bongkot (sebutan warna kecoklatan yang biasa digunakan oleh masyarakat setempat) [1]. Berdasarkan kondisi tersebut terdapat peluang inovasi pada produk khas Citumang dengan memberikan warna pada serat tersebut dengan proses pewarnaan alami.

Proses pewarnaan alami menggunakan bahan pewarna alami dari tanaman Secang (Caesalpinia sappan). Pewarnaan menggunakan secang ini akan menghasilkan warna bernuansa jingga, merah muda, hingga ungu [5]. Pertimbangan lainnya memilih menggunakan pewarna alami secang ini adalah karena bahan pewarna ini dapat dengan mudah ditemukan di sekitar Kabupaten Pangandaran. Berdasarkan hasil perbandingan tersebut proses pewarnaan paku hata dilakukan dengan menggunakan sumber pewarna secang yang diproses tanpa tahapan scouring dan bleaching kemudian dilakukan proses fiksasi dengan mordant cuka, kapur sirih dan tunjung. Adapun pertimbangan eksperimen menggunakan pewarna alami secang adalah ketersediaan bahan baku pewarna alami ini yang melimpah dan mudah ditemukan di kawasan Citumang. Selain itu pewarna alami secang mudah untuk diaplikasikan karena memiliki pigmen warna yang mudah diekstrak. Dengan begitu untuk masyarakat pengrajin Citumang yang baru belajar menggunakan pewarna alami tidak akan kesulitan mempelajarinya.

Tabel 1. Hasil Eksperimen Pewarnaan Alami Serat Paku Hata

\begin{tabular}{|c|l|c|l|}
\hline No & \multicolumn{1}{c|}{ Proses } & \multicolumn{1}{c|}{ Analisa } \\
\hline 1 & $\begin{array}{l}\text { Menggunakan pewarna } \\
\text { secang } 1 / 4 \text { ons, air sebanyak } \\
2,5 \text { liter dengan mordant cuka } \\
\text { awal direbus selama } 30 \text { menit }\end{array}$ \\
\hline 2 & $\begin{array}{l}\text { Menggunakan pewarna } \\
\text { secang } 1 / 4 \text { ons, air sebanyak } \\
\text { cuk liter dengan mordant } \\
\text { menit }\end{array}$ & $\begin{array}{l}\text { Warna coklat muda, } \\
\text { warna lembut, } \\
\text { menyerap merata pada } \\
\text { permukaan dalam dan } \\
\text { luar paku hata. }\end{array}$ \\
\hline
\end{tabular}




\begin{tabular}{|c|c|c|}
\hline 3 & $\begin{array}{l}\text { Menggunakan pewarna } \\
\text { secang } 1 / 4 \text { ons, air sebanyak } \\
2,5 \text { liter dengan mordant } \\
\text { kapur sirih awal direbus } \\
\text { selama } 30 \text { menit }\end{array}$ & $\begin{array}{l}\text { Warna coklat pucat, } \\
\text { tidak memberi } \\
\text { perbedaanwarna } \\
\text { sgnifikan dari warna } \\
\text { asli paku hata, warna } \\
\text { menyerap merata pada } \\
\text { kedua sisi paku hata. }\end{array}$ \\
\hline 4 & $\begin{array}{l}\text { Menggunakan pewarna } \\
\text { secang } 1 / 4 \text { ons, air sebanyak } \\
2,5 \text { liter dengan mordant } \\
\text { kapur sirih akhir direbus } \\
\text { selama } 60 \text { menit }\end{array}$ & $\begin{array}{l}\text { Warna ungu kecoklatan, } \\
\text { warna menyerap lebih } \\
\text { pekat dan gelap, warna } \\
\text { juga menyerap secara } \\
\text { merata pada kedua sisi } \\
\text { paku hata. }\end{array}$ \\
\hline 5 & $\begin{array}{l}\text { Menggunakan pewarna } \\
\text { secang } 1 / 4 \text { ons, air sebanyak } \\
2,5 \text { liter dengan mordant } \\
\text { tunjung awal direbus selama } \\
30 \text { menit }\end{array}$ & $\begin{array}{l}\text { Warna abu tua, warna } \\
\text { menyerap lebih merata } \\
\text { pada bagian luar dan } \\
\text { dalam paku hata, hasil } \\
\text { warna lebih pekat. }\end{array}$ \\
\hline 6 & $\begin{array}{l}\text { Menggunakan pewarna } \\
\text { secang } 1 / 4 \text { ons, air sebanyak } \\
2,5 \text { liter dengan mordant } \\
\text { tunjung akhir direbus selama } \\
60 \text { menit }\end{array}$ & $\begin{array}{l}\text { Warna hitam pekat, } \\
\text { warna menyerap pada } \\
\text { kedua sisi permukaan } \\
\text { paku hata walau di } \\
\text { beberap abagian ada } \\
\text { yang kurang rata. }\end{array}$ \\
\hline
\end{tabular}

Kesimpulan dari eksperimen pewarnaan alami ini adalah proses pewarnaan alami dapat diterapkan pada serat paku hata, di mana setelah pencelupan menggunakan pewarna dan proses fiksasi dihasilkan serat paku hata yang mengalami perubahan warna dibandingkan warna asli sebelumnya. Hal ini menunjukan serat paku hata memiliki kemampuan menyerap zat warna alami. Begitupun dengan penggunaan mordant berupa cuka, kapur sirih dan tunjung pun dapat menghasilkan warna yang bervariasi mulai dari coklat, ungu, abu dan hitam.

Selanjutnya adala eksperimen penerapan hasil pewarnaan alami tersebut kepada masyarakat pengrajin serat paku hata di Citumang. Hal ini bertujuan untuk mengukur kemampuan masyarakat tersebut dalam mengadaptasi inovasi tersebut. Berdasarkan hasil eksperimen tersebut didapatkan bahwa masyakarat Citumang mampu merespon dengan positif. Bahkan mereka antusias untuk menerapkan teknik pewarnaan alami ini pada produk mereka. Tahap ini penting sebelum melanjutkan tahap ekseprimen selanjutnya, untuk melihat apakah pewarna alami merupakan teknologi tepat guna yang sesuai dengan kebutuhan dan kemampuan masyarakat tersebut.
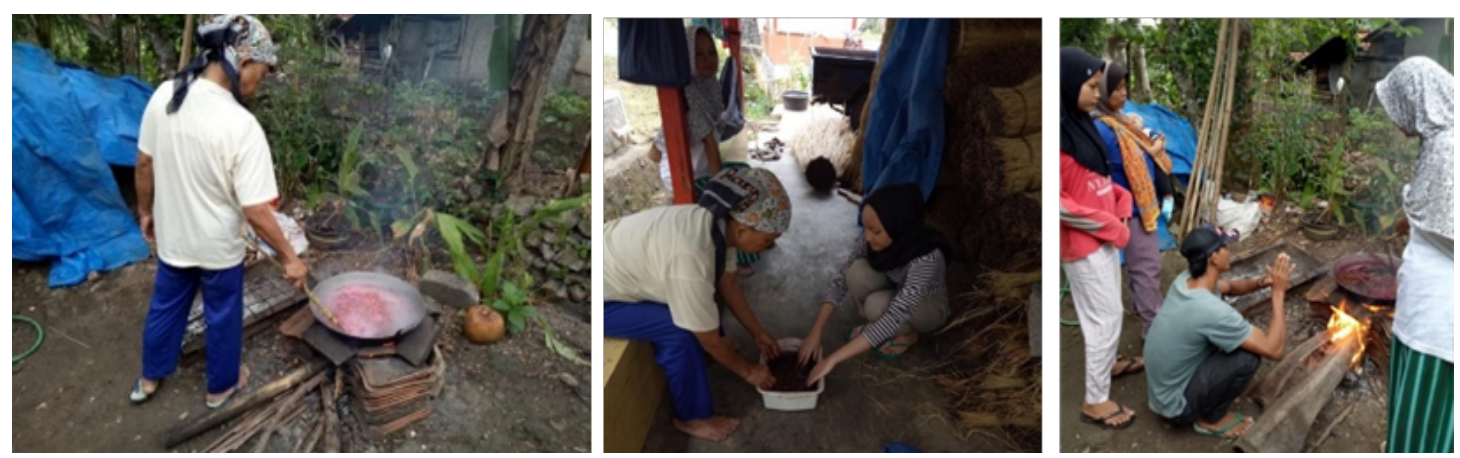

Gambar 3. Proses Eksperimen Pewarnaan Alami Secang pada Serat Paku Hata oleh Para Pengrajin di Citumang (Sumber: Firstriani, 2018).

\section{Eksperimen Proses Aplikasi Imbuh pada Produk Kerajinan Khas Citumang}

Eksperimen selanjutnya yang dilakukan untuk meningkatkan inovasi pada produk kerajinan paku hata khas Citumang adalah memberikan aplikasi imbuh dipermukaan anyaman paku hata tersebut. Selama ini produk-produk kerajinan tas paku hata khas Citumang masih dibuat dengan polos tanpa ada pengaplikasian apapun diatas permukaannya. Maka dengan adanya penambahan desain struktur ini 
diharapkan mampu memberikan tampilan yang baru pada produk di Citumang. Hal-hal yang dijadikan sebagai pertimbangan dalam proses eksperimen ini, antara lain: 1) Motif memilih bentuk-bentuk geometris untuk mengikuti pola anyaman dasar yang berpola geometris, dengan inspirasi diambil dari bentuk-bentuk ragam hias yang telah mampu dibuat oleh pengrajin di Citumang dengan menggunakan cat minyak; dan 2) teknik sulam dipilih menyesuaikan pada karakteristik serat paku hata yang berbentuk helaian panjang.

Tabel 2. Hasil Eksperimen Aplikasi Imbuh pada Kerajinan Paku Hata Khas Citumang

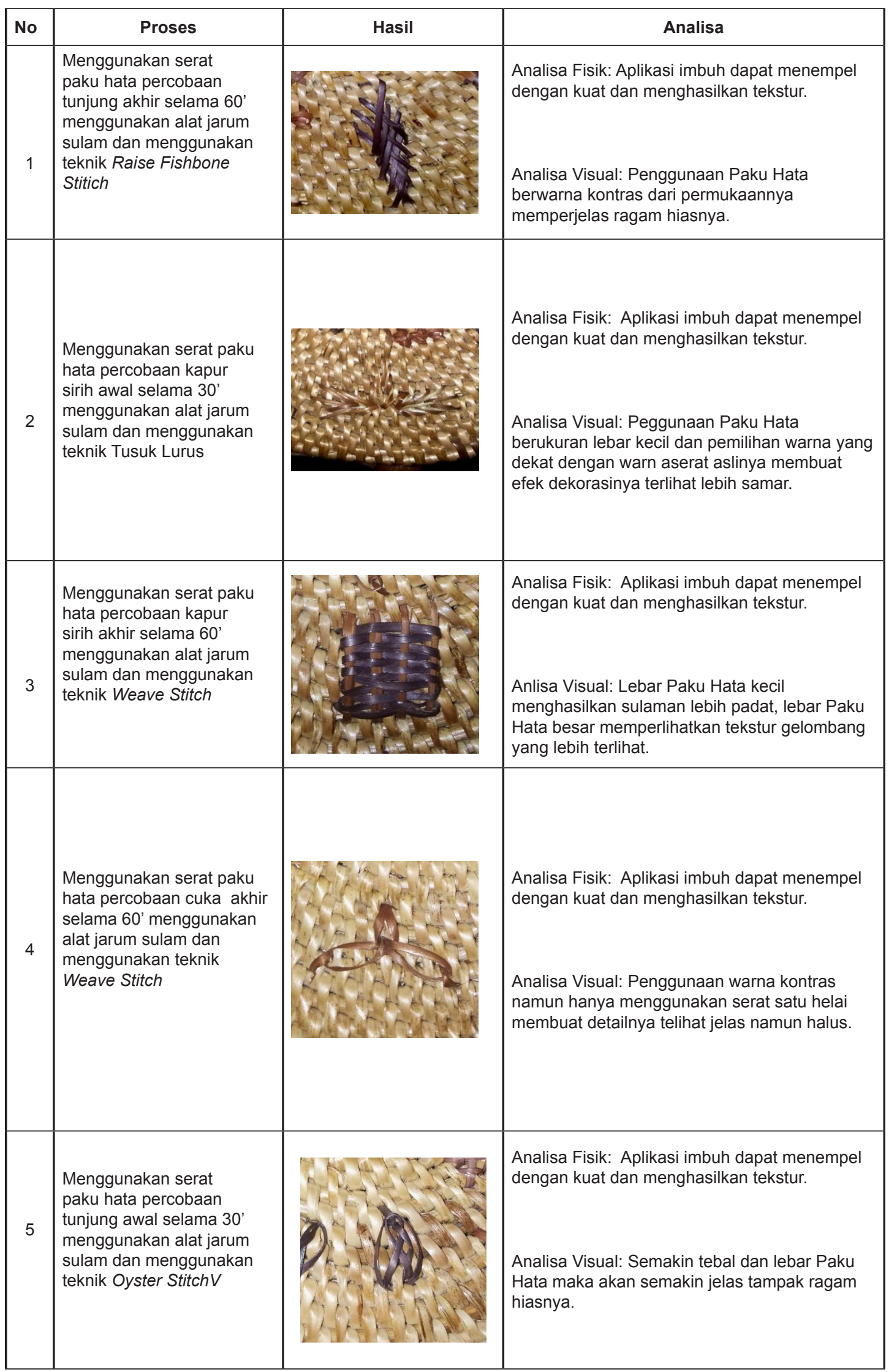


Setelah dilakukan proses eksperimen desain struktur berupa sulam pada produk kerajinan, maka selajutnya eksperimen tersebut diterapkan kembali kepada masyarakat Citumang untuk mendapat pelatihan bagaimana mengaplikasikan sulaman tersebut diatas produk kerajinan mereka. Berdasarkan hasil eksperimen bersama masyarakat Citumang, tampak bahwa aplikasi imbuh ini pun dapat diterima dengan baik. Masyarakat Citumang mengalami peningkatan dalam hal keterampilan untuk mengaplikasikan teknik aplikasi imbuh, serta sekaligus berampak pula terhadap penampilan visual produk kerajinan mereka secara signifikan dibandingkan sebelumnya.

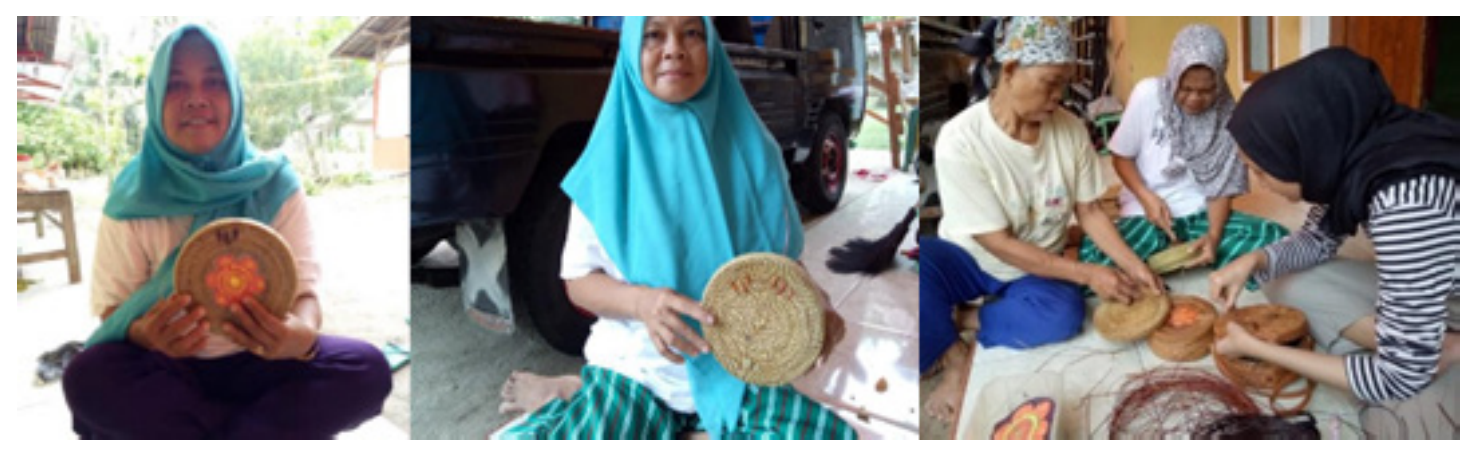

Gambar 4. Proses Eksperimen Teknik Sulam pada Permukaan Serat Paku Hata oleh Para Pengrajin di Citumang (Sumber: Firstriani, 2018)

\section{Eksperimen Komposisi Motif Produk Kerajinan Paku Hata Khas Citumang}

Eksperimen terakhir dilakukan untuk dapat menampilkan variasi inovasi yang berbeda pada produk tas serat paku hata di Citumang, dari yang sebelumnya hanya polos, dapat menghasilkan variasi corak motif dan komposisi yang lebih menarik dan dekoratif. Pada ekseprimen ini komposisi motif dibuat dengan menggunakan simulasi secara digital sebelum akhirnya diterapkan kepada para pengrajin anyaman di Citumang. Proses ini dilakukan dengan menggunakan software Adobe Illustrator.

Tabel 3. Hasil Eksperimen Komposisi Warna pada Produk Khas Citumang.

\begin{tabular}{|c|c|c|}
\hline No & Hasil Simulasi Desain & Analisa \\
\hline 1 & & $\begin{array}{l}\text { Menampilkan irama dan proporsi dengan } \\
\text { ragam hias geometris yang menyerupai } \\
\text { efek pixel. }\end{array}$ \\
\hline 2 & & $\begin{array}{l}\text { Menampilkan kesatuan dan irama yang } \\
\text { terstruktur serta menampilkan paduan } \\
\text { warna yang padat, serta bentuk motif } \\
\text { terlihat jelas berupa bunga dengan } 8 \\
\text { kelopak. }\end{array}$ \\
\hline
\end{tabular}




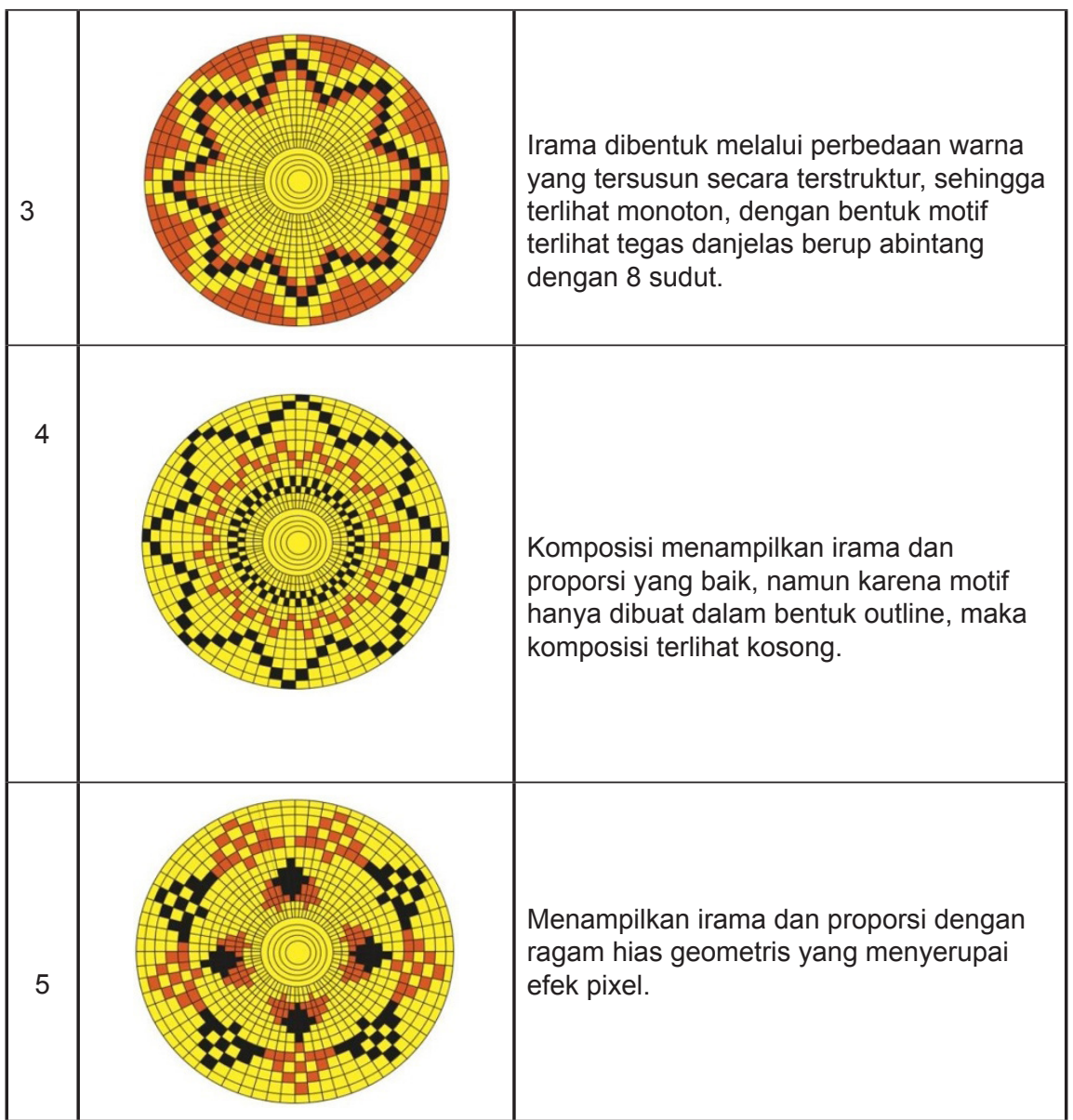

Hasil dari eksperimen tersebut dengan melakukan simulasi motif menggunakan bantuan software Adobe Illustrator mampu memberikan gambaran tentang arah pengembangan motif ke depannya. Selanjutnya simulasi desain tersebut diterapkan pada pengrajin anyaman paku hata di Citumang dengan menerapkan teknik anyaman coil. Dengan menggunakan teknik anyam coil tersebut, para pengrajin Citumang dapat bersandar terhadap keterampilan dasar yang sudah mereka miliki sebelumnya, namun tetap memiliki tantangan untuk meningkatkan kreativitas pada penambahan serat paku hata berwarna dan penempatan benang berwarna untuk menciptakan komposisi pada saat menganyam.

\section{KESIMPULAN}
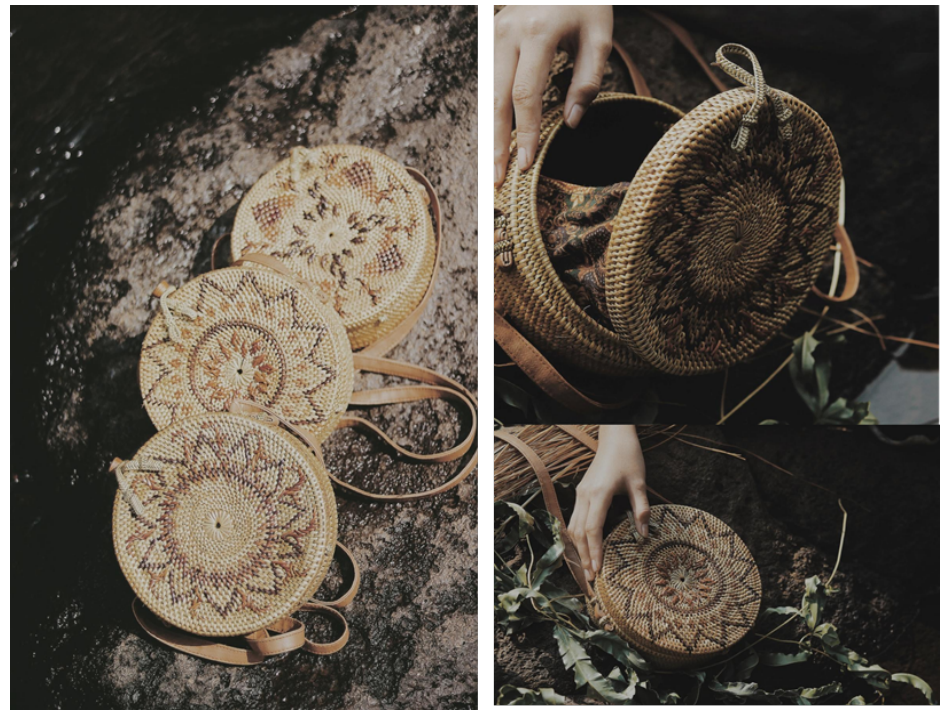

Gambar 5.Visualisasi Produk Inovasi Pengembangan Kerajinan Paku Hata Khas Citumang

Dengan memanfaatkan sumber daya alam paku hata yang melimpah dan melakukan tahapan eksperimen pada kerjajinanan serat paku hata tersebut, maka telah mampu dihasilkan sebuah inovasi pada produk kerajinan serat paku hata yang dapat menonjolkan sisi kekhasan yang membedakannya dengan produk sejenis dari Bali dan Lombok. Selain itu bukan hanya inovasi pada aspek estetis visual saja, melainkan juga adanya peningkatan keterampilan dan wawasan para pengrajin di Citumang dalam 
hal mewarnai serat dengan pewarna alami, memberikan aplikasi imbuh pada permukaan anyaman serat paku hata, dan juga penerapan komposisi motif dengan Teknik coil.

Eksperimen pewarnaan alami dilakukan dengan bahan pewarna alami secang tanpa proses scouring dan bleaching dengan zat mordant garam dan tunjung untuk menghasilkan warna merah kecoklatan dan hitam. Proses pewarnaan dapat dilakukan dengan baik dan para pengrajin dapat mengikuti langkah proses pewarnaan dengan baik pula. Setelah eksperimen pewarnaan berhasil maka selanjutnya adalah ekperimen penerapan benang hasil pencelupan dengan teknik aplikasi imbuh di atas permukaan lembaran anyaman serat paku hata. Terakhir adalah eksperimen komposisi motif yang dilakukan dengan bantuan software Adobe Illustrator untuk menghasilkan simulasi motif untuk selanjutnya diterapkan oleh para pengrajin anyaman dengan teknik coil.

Dapat disimpulkan bahwa melalui serangkaian tahapan eksperimen ini dapat menciptakan ciri khas pada kerajinan paku hata di Citumang. Hal ini bukan hanya menghasilkan pembeda pada tampilan estetik visualnya saja, melainkan telah memperkenalkan teknologi tepat guna di bidang kriya kepada para pengrajin untuk melanjutkan inovasi ke depannya.

\section{KESIMPULAN}

[1] Firstriani, R. \& Ciptandi, F. 2019. Development of Paku Hata Craft Products in Citumang, West Java. In 6th Bandung Creative Movement (pp. 120-124). Telkom University.

[2] Arini \& Kinho. Keragaman jenis Tumbuhan Paku (Pteridophyta) di Cagar Alam Gunung Ambang Sulawesi Utara. 2012. Balai Penelitian Kehutanan Manado.

[3] Tim Studi dan kementrian Pariwisata Ekonomi Kreatif. 2015. Ekonomi Kreatif: Rencana Pengembangan Kerajinan Nasional 2015-2019. Jakrta: PT Republik Resolusi.

[4] Baskertry Techiques. 2013. Diunduh dan diakses dari sumber internet pada tanggal 26 Juli 2020, pada link : www.basketryandbeyond.org.uk

[5] Fitriyah, H., \& Ciptandi, F. (2018). Pengolahan Limbah Sabut Kelapa Tua Sebagai Pewarna Alam Pada Produk'Fesyen. eProceedings of Art \& Design, 5(3).

[6] Fitriani, H., \& Ciptandi, F. (2017). Pengolahan Kulit Umbi Singkong (manihot Utilissima) Di Kawasan Kampung Adat Cireundeu Sebagai Bahan Baku Alternatif Perintang Warna Pada Kain. eProceedings of Art \& Design, 4(3). 